\title{
The prevalence of arterial hypertension depending on selected demographic factors among adult residents of eastern Poland district
}

\author{
Monika Klimek', Paulina Mulawka², Tytus Tulwin ${ }^{3}$, Grzegorz Jan Dzida² \\ ${ }^{1}$ Medical University of Lublin \\ ${ }^{2}$ Chair and Department of Internal Diseases, Medical University of Lublin \\ ${ }^{3}$ Department of Thermodynamics, Fluid Mechanics and Aircraft Propulsion, Lublin University of Technology
}

\begin{abstract}
Background. Identification and analysis of risk factors are important aspects of planning the long-term actions to prevent, early diagnose and properly treat hypertension. The aim of this study was to examine the prevalence of hypertension and to determine the relationship between the prevalence of hypertension and selected sociodemographic factors among adult residents of a typical eastern Poland district.

Material and methods. The study involved 1225 residents of the Janów Lubelski district aged between 36 and 65 years. The research methodology included a questionnaire survey. Blood pressure, body weight and height were measured, the BMI was calculated. Statistical analysis was performed.

Results. $26.8 \%$ of subjects are treated for hypertension. $32.9 \%$ of hypertensive subjects are treated properly and women have better control of hypertension than man $(41.3 \%$ vs. 19.7\%). Among subjects without treatment for hypertension, $37.5 \%$ of them have abnormally high blood pressure and it is more common in men $(58.9 \%$ vs. $43.4 \%)$. The prevalence of hypertension increased with age. The percentages are from $8.6 \%$ for subjects aged 36-40 to $45.7 \%$ for subjects aged 61-65. Higher prevalence of hypertension is observed in men below the age of 50 compared to women. There is the significant rising prevalence of hypertension in women above the age of 50 . The relationship between the prevalence of hypertension and the educational background is demonstrated. Among subjects with elementary education, the prevalence of hypertension is higher (45.5\%) as compared to subjects with higher education (18.2\%). Area of residence and marital status have no effects on the prevalence of hypertension.

Conclusions. The prevalence of hypertension was lower compared to other epidemiological studies. Improvements in hypertension control have been observed for many years. The educational background has an important influence on the prevalence of hypertension. Further studies are required to establish the influence of an area of residence and marital status on the prevalence of hypertension.
\end{abstract}

Key words: arterial hypertension; prevalence; sociodemographic factors

Arterial Hypertens. 2018, vol. 22, no. 4, pages: 172-178

DOI: 10.5603/AH.a2018.0017

Address for correspondence: Prof. Grzegorz Jan Dzida, MD, PhD

Chair and Department of Internal Diseases, Medical University of Lublin

e-mail: grzegorz.dzida@wp.pl

V M Copyright (C) 2018 Via Medica, ISSN 2449-6170 


\section{Introduction}

Arterial hypertension similarly to other cardiovascular diseases is civilization-related disease highly dependent on modifying environmental risk factors such as obesity, lack of physical activity, unhealthy diet, excessive salt intake, smoking. Development and course of arterial hypertension depend also on sociodemographic factors, which are unmodifying risk factors for arterial hypertension. Age, gender, race, genetics, the area of residence, marital status, educational background are classed as sociodemographic factors. Identification and analysis of selected risk factors enable to plan the long-term actions to prevent, early diagnose and properly treat arterial hypertension, which is essential in preventing premature cardiovascular mortality. The aim of this study is to examine the prevalence of arterial hypertension and to determine the relationship between the prevalence of arterial hypertension and selected sociodemographic factors among adult residents of a typical eastern Poland district.

\section{Material and methods}

The study was conducted in years 2009-2016 as part of free public health promotion project "Take Your Health to Your Heart", financed by the Norway Grants. The study was aimed at analyzing the health status of the residents of the Janów Lubelski district within the Lublin voivodeship, at identifying the residents' needs with regard to the reduction of cardiovascular risk, and at taking appropriate measures to reduce inequalities in health chances as compared to more affluent regions of Poland. The research methodology for this study included a questionnaire survey. The first part of the questionnaire consisted of questions pertaining to selected sociodemographic data (gender, age, educational background, the area of residence, marital status) while the second part surveyed the medical history and current health of subjects. Blood pressure, body weight and height were measured; then, the body mass index (BMI) was calculated. The subject was considered to be overweight if the BMI was $25-29.99 \mathrm{~km} / \mathrm{m}^{2}$ and obese if it was $\geq 30 \mathrm{~kg} / \mathrm{m}^{2}$. Blood pressure measurements were performed by qualified personnel (nurses, physicians) in sitting position after at least 15-minute resting period. In the case of abnormally high arterial blood pressure measurements, blood pressure was measured twice and the result was average blood pressure.
Since the primary aim of this study was to examine the prevalence of arterial hypertension, the tool to establish the objective diagnosis was needed. Subjects' knowledge about their diagnosis might be limited, so only subjects treated for arterial hypertension were considered to be suffering form arterial hypertension. The group with abnormally high arterial blood pressure measurements (systolic blood pressure $\geq 140 \mathrm{~mm} \mathrm{Hg}$ and/or diastolic blood pressure $\geq 90 \mathrm{~mm} \mathrm{Hg}$ according to $2013 \mathrm{ESH} / \mathrm{ESC}$ and PTNT 2015 guidelines) was discussed separately, since blood pressure measurements at one appointment as in this study is not enough to diagnose arterial hypertension, but should be further diagnosed. The patients from this group were informed about the necessity of further investigation.

A total of 1225 residents of the Janów Lubelski district, aged 36 to 65 , reported to take part in the study. For a more detailed analysis of results, the subjects were subcategorized into 5 -year age range groups $(36-40,41-45,46-50,51-55,56-60$, 61-65). The results were processed using the MS Office 2016 suite and the Statistica StatSoft package (academic license for the Lublin University of Technology). The relationship between the prevalence of arterial hypertension and the sociodemographic factors (gender, age, educational background, area of residency, marital status) was analyzed using the chi-square test of independence and $p<0.05$. The results are presented with the accuracy of one decimal place (0.1).

\section{Results}

The study was conducted in 1225 subjects aged 36 to 65 years, average age $51.3 \pm 8.4 \mathrm{SD}$. More details on demographic factors including age, gender, educational background, the area of residence, marital status are presented in Table I.

Out of the study population, $26.8 \%$ of subjects are treated for arterial hypertension, whereas $73.2 \%$ are not on antihypertensive treatment. Even though subjects with arterial hypertension in the study group take antihypertensive drugs, most of them (67.1\%) have inaccurate blood pressure values. Only $32.9 \%$ of hypertensive subjects are treated effectively. It is stated that women have better control of arterial hypertension (41.3\% properly treated) as compared to men $(19.7 \%)(p<0.001)$. Among subjects without treatment for arterial hypertension, $27.4 \%$ of study group have abnormally high arterial blood pressure measurements and require further investigation, while only less than half of all subjects (45.8\%) have 
Table I. Characteristic of study population

\begin{tabular}{|l|c|c|}
\hline & Number (n) & Percentage (\%) \\
\hline Age & & \\
$36-40$ & 163 & $13.3 \%$ \\
$41-45$ & 206 & $16.8 \%$ \\
$46-50$ & 199 & $16.2 \%$ \\
$51-55$ & 197 & $16.1 \%$ \\
$56-60$ & 250 & $20.4 \%$ \\
$61-65$ & 210 & $17.1 \%$ \\
\hline Gender & & \\
Women & 742 & $60.6 \%$ \\
Men & 483 & $39.4 \%$ \\
\hline Educational background & & \\
Elementary & 99 & $8.1 \%$ \\
Vocational & 386 & $31.5 \%$ \\
Secondary & 416 & $34.0 \%$ \\
Higher & 324 & $26.4 \%$ \\
\hline Area of residence & & \\
Rural & 620 & $50.6 \%$ \\
Urban & 605 & $49.4 \%$ \\
\hline Marital status & & \\
Married & 1070 & $87.3 \%$ \\
Single & 155 & $12.7 \%$ \\
\hline
\end{tabular}

accurate blood pressure values and do not require further investigation (Fig. 1).

The percentages of subjects treated for arterial hypertension are comparable between genders and amount $27.1 \%$ in women and $26.3 \%$ in men. Age structural differences between suffering from arterial hypertension women and men are observed. In men below the age of 50 compared to women, arterial hypertension is almost two times more frequent. In men above the age of 50 , the percentage of subjects suffering from arterial hypertension still increases and there is the significant rising prevalence of arterial hypertension in women older than 50 years of age (Fig. 2).
Incorrect blood pressure values among subjects untreated for arterial hypertension are more frequent in men (58.9\%) compared to women (43.4\%) $(\mathrm{p}<0.001)$ (Fig. 3).

The prevalence of arterial hypertension increases with age. The respective percentages are from $8.6 \%$ for subjects aged $36-40$ to $45.7 \%$ for subjects aged $61-65$ ( $\mathrm{p}<0.001)$. Among subjects below the age of 50 , the percentage of suffering from arterial hypertension is lower than the average percentage of suffering from arterial hypertension in the whole study population, while above the age of 50 is higher. The percentages of suffering from arterial hypertension in age groups are presented in Figure 4.

Among subjects with elementary education the prevalence of arterial hypertension is evidently higher (45.5\%), compared to subjects with vocational, secondary and higher education $(\mathrm{p}<0.001)$. The lowest percentage of subjects with arterial hypertension is in a group with higher education and amounts $18.2 \%$ (Fig. 5).

There is no correlation between the prevalence of arterial hypertension, the area of residence and marital status of the study population.

\section{Conclusions}

In this study the prevalence of arterial hypertension $(26.8 \%)$ is lower than in previous epidemiological studies: $29-36 \%[1,2]$. According to latest large population study, LIPIDOGRAM 2015 conducted in years 2015-16, the prevalence of arterial hypertension is $40 \%$ (average age of subjects 56.3 years old), which suggests that in Poland about 15 million people suffer from arterial hypertension [3]. The Polish nationwide multicenter population health study (WOBASZ) is important not only because

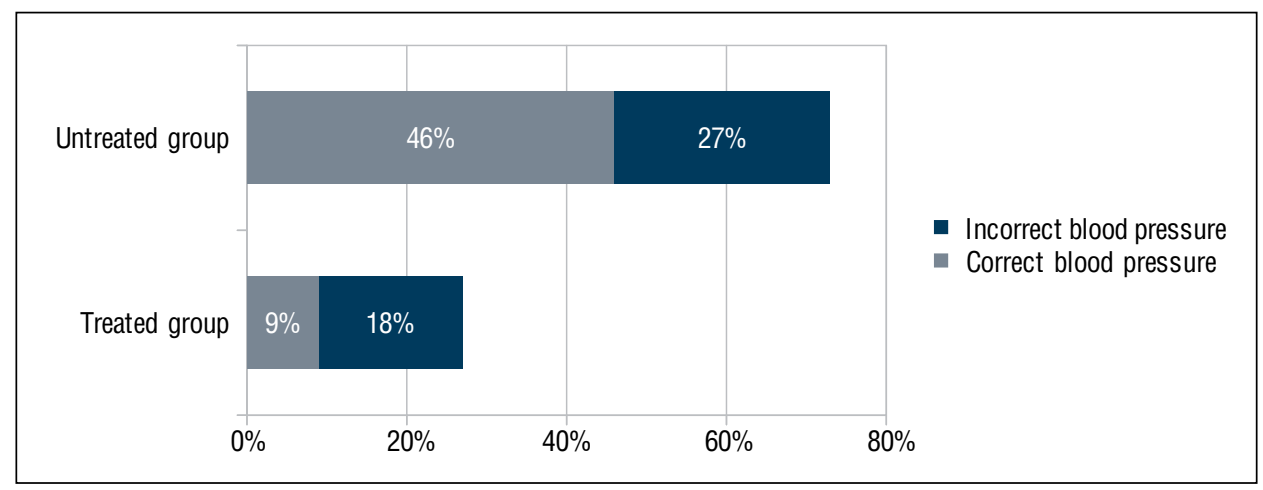

Figure 1. The percentages of subjects untreated (1) and treated (2) for arterial hypertension. Blue colour — subjects with correct blood pressure during the study, red colour — subjects with incorrect blood pressure 


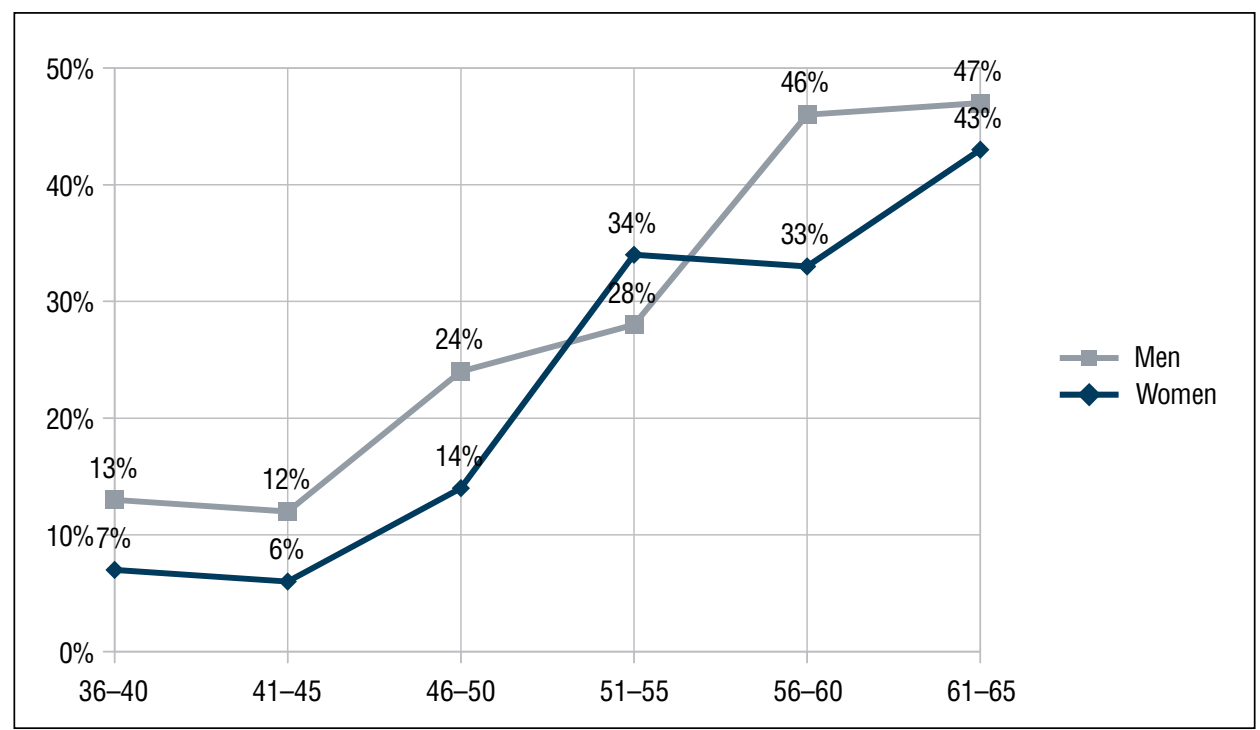

Figure 2. Percentage of subjects treated for arterial hypertension depending on gender and age

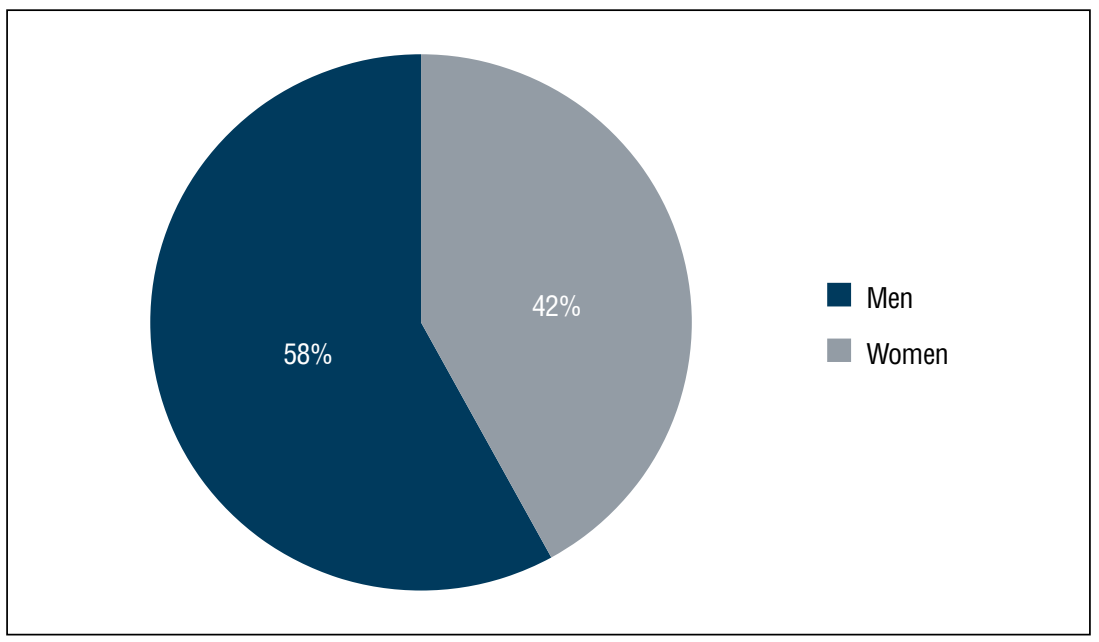

Figure 3. Incorrect blood pressure values among untreated women and men

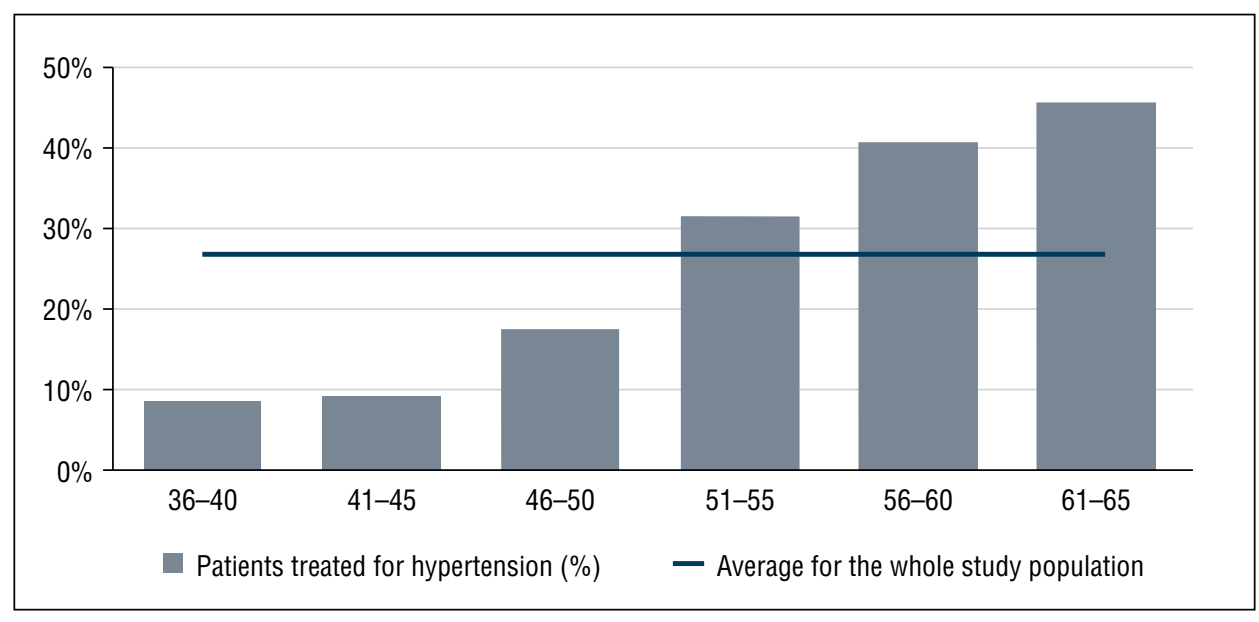

Figure 4. Age structure of subjects suffering from arterial hypertension 


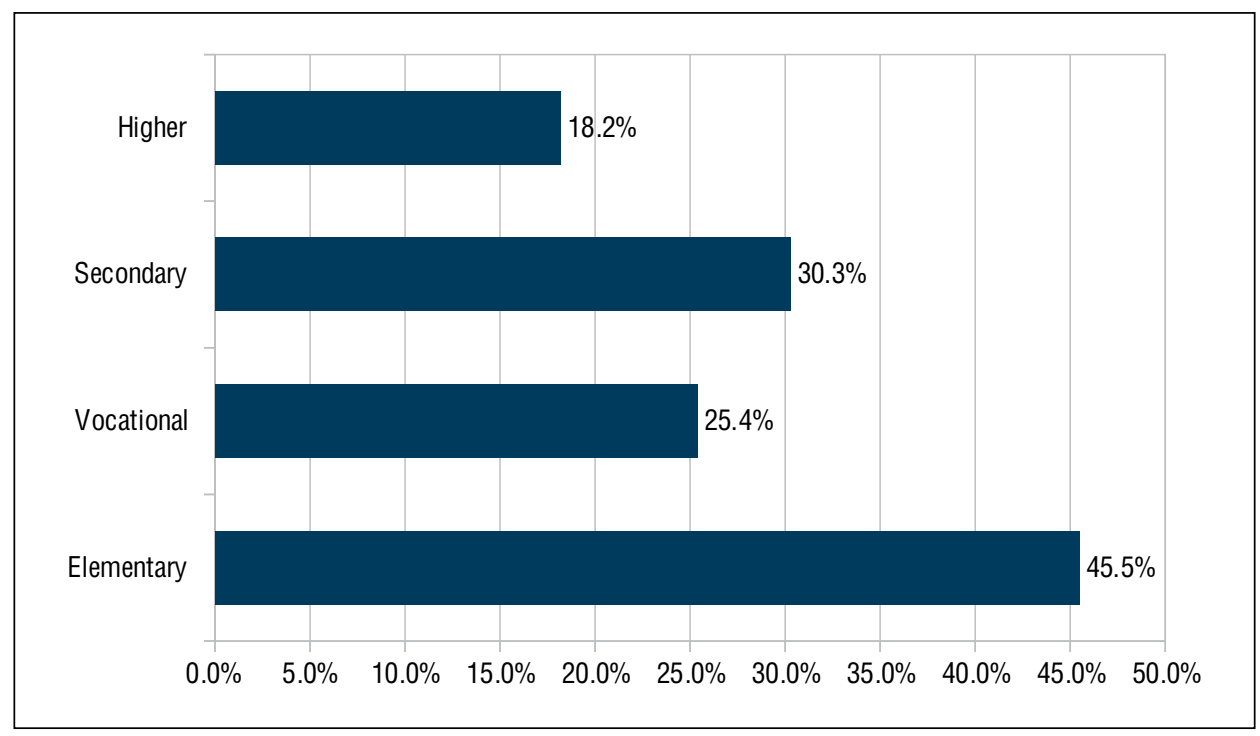

Figure 5. The prevalence of arterial hypertension depending on educational background

of large population, correct methodology and how the study was carried out but also because the residents of specific regions of Poland' health status was established. Large differences in the prevalence of arterial hypertension between specific voivodeship were observed. Based on the results of WOBASZ study, the comparison of prevalence in all voivodeship was made. In Lublin voivodeship population the prevalence of cardiovascular diseases is low as compared to the entire country. According to WOBASZ study, the prevalence of arterial hypertension in Lublin voivodeship is $24 \%$ in women and men, which is the lowest percentage in the entire country (average women $32.9 \%$, men $42,1 \%$ [2, 4].

Out of the study population, $26.8 \%$ of the subjects are on antihypertensive treatment. These results are comparable to observations on the health status of Polish population performed by Central Statistical Office in 2014, where antihypertensive treatment was taken by $21 \%$ of respondents [5].

It is difficult to determine the prevalence of arterial hypertension using interview about antihypertensive therapy since as NATPOL 2011 study presented $28 \%$ of suffering from arterial hypertension subjects are not aware of their disease and $38 \%$ of subjects with diagnosed arterial hypertension do not take recommended therapy [1]. As a part of the project titled "Take Your Health to Your Heart", the blood pressure was measured during only one day, which does not allow to diagnose arterial hypertension according to guidelines. Taking into consideration the results of NATPOL 2011, we might suspect that among untreated subjects with incorrect blood pressure values
(27.4\% of study population) there is a large group of subjects with undiagnosed arterial hypertension. If we recognize this group of subjects as ill, it will mean that more than half $(50.6 \%)$ of ill subjects do not know about their disease.

When it comes to antihypertensive therapy, the important issue is the efficacy of the treatment. The percentage of controlled hypertensive Polish patients increased over years and it was $12 \%$ (NATPOL, 2002), 14.1\% (WOBASZ, 2005), 23\% (NATPOL, 2011) $[1,2]$. This study confirms the increasing trend, it was demonstrated that $32.9 \%$ of suffering from arterial hypertension are good controlled. Although the percentage of controlled hypertensive patents increased, it is still low as compared to the United States, where this percentage is 52\% [6]. The efficacy o treatment varies according to gender with more than twice better efficacy in women $(41.3 \% v$ s. $19.7 \%$ ) what was observed also in NATPOL PLUS study $(14 \%$ vs. $10 \%)$ and WOBASZ study (14-16\% vs. $9-10 \%)[1,2]$. This fact is explained by better women compliance with a physician.

The results of the study suggest that age and educational background are important factors, which influence the prevalence of arterial hypertension in population. The prevalence of arterial hypertension is comparable in both genders. Taking into consideration the results of different studies, it seems that arterial hypertension is more prevalent in men $[1,2$, 7]. The number of cases of arterial hypertension increases with age in both genders, but in men earlier, whereas there is the significant rising prevalence of arterial hypertension in women above the age of 50 


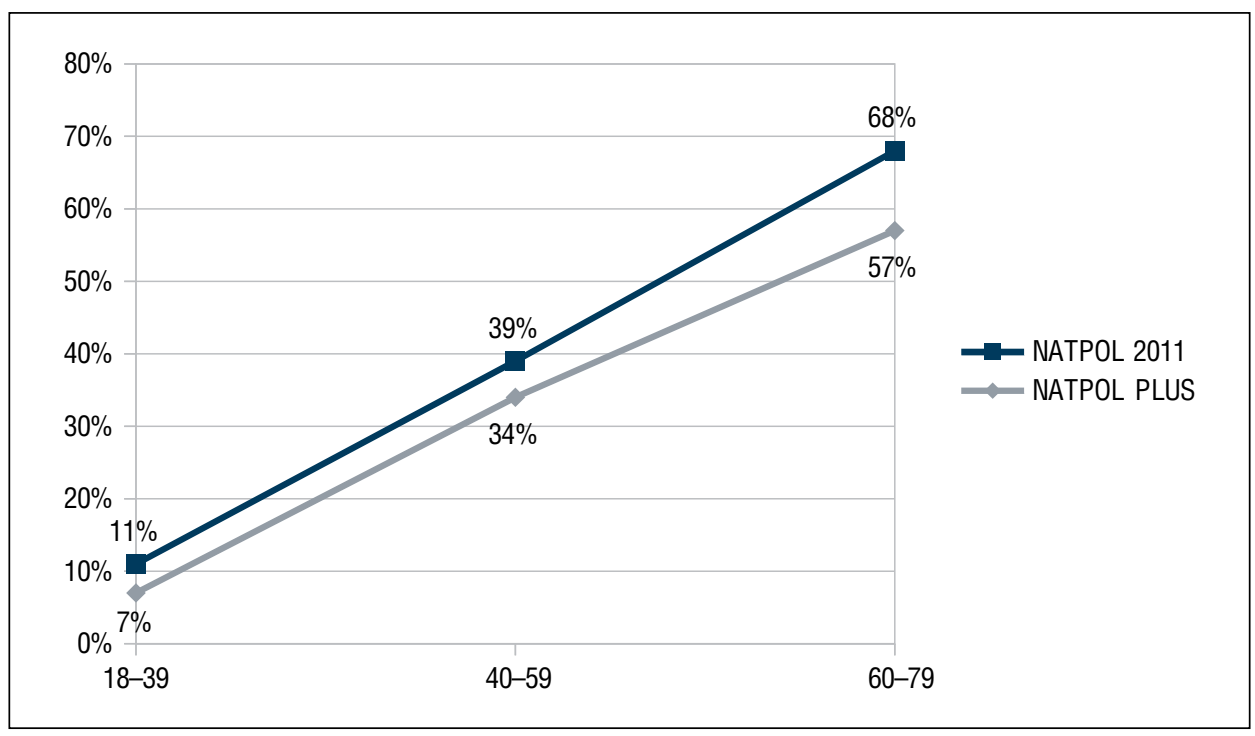

Figure 6. The prevalence of arterial hypertension in age groups in NATPOL 2011 and NATPOL PLUS

and in this age group women dominate. Higher prevalence of arterial hypertension in older age groups is confirmed by studies NATPOL PLUS 2002 and NATPOL 2011 (Fig. 6).

In this study important relationship between educational background and arterial hypertension was demonstrated, that confirm previous reports about the increased prevalence of cardiovascular diseases among low educated people. It was proven that low education background is connected with increased cardiovascular risk, higher prevalence of diabetes, hypercholesterolemia, hypertriglyceridemia [8], obesity and arterial hypertension [1, 8-12].

The results of this study do not demonstrate a correlation between arterial hypertensiona, marital status and area of residence. However, this issue demands further investigation, since existing data are contradictory $[13,14]$.

\section{Conflicts of interests}

The authors declare no conflicts of interests.

The study was conducted as a part of the project titled "Take Your Health to Your Heart - a health promotion and cardiovascular disease prevention program for the Janów Lubelski district", supported through the Norwegian Financial Mechanism as part of the PL 13 Task "Reducing health inequalities" for years 2009-2014 and the state budget funds.

\section{References}

1. Zdrojewski T, Rutkowski M, Bandosz P, Gaciong Z, Solnica B, Drygas W, Wojtyniak B, Stokwiszewski J, Pencina M, Wołkiewicz E, Piwoński J, Jędrzejczyk T, Grodzicki T, Wyrzykowski B. Ocena rozpowszechnienia i kontroli czynników ryzyka chorób serca i naczyń w Polsce - badania NATPOL 1997, 2002, 2011. In: Kopeć G, Jankowski P, Pająk A, Drygas W. ed. Epidemiologia i prewencja chorób układu krażenia. Medycyna Praktyczna, Kraków 2015: 57-64.

2. Tykarski A, Posadzy-Małaczyńska A, Wyrzykowski B, et al. Rozpowszechnienie nadciśnienia tętniczego oraz skuteczność jego leczenia u dorosłych mieszkańców naszego kraju. Wyniki programu WOBASZ. Kardiol Pol. 2005; 63(Suppl IV): S614-S619.

3. Jóźwiak J, Mastej M, Windak A, Tomasik T, Lukas W, Skowron $€$. Rozpowszechnienie klasycznych czynników ryzyka chorób sercowonaczyniowych w oulacji 13724 acjentów POZ w Polsce. Wyniki badania LIPIDOGRAM2015 \& LIPIDOGEN2015. In: Kardiologia prewencyjna 2017: wytyczne, wątpliwości, gorące tematy. X Konferencja Naukowa Sekcji Prewencji i Epidemiologii PTK Kraków, 17-18 listopada 2017. , Kraków 2017: 87.

4. Drygas W, Bielecki W, Kozakiewicz K, Pająk A, Piotrowski W, Tykarski A. Wieloośrodkowe Ogólnoolskie Badanie Stanu Zdrowia Ludności: WOBASZ. In: Drygas W, Kopeć G, Jankowski P, Pająk A. ed. Epidemiologia i prewencja chorób układu krążenia. Medycyna Praktyczna, Kraków 2015: 41-56.

5. Główny Urząd Statystyczny. Stan zdrowia ludności Polski w 2014 r. https://stat.gov.pl/obszary-tematyczne/zdrowie/zdrowie/stanzdrowia-ludnosci-polski-w-2014-r-.6.6.html (25.09.2018).

6. Nwankwo T, Yoon SS, Burt V, et al. Hypertension among adults in the United States: National Health and Nutrition Examination Survey, 2011-2012. NCHS Data Brief. 2013(133): 1-8, indexed in Pubmed: 24171916.

7. Sulicka J, Fornal M, Gryglewska B, et al. Wybrane czynniki ryzyka chorób sercowo-naczyniowych u pacjentów podstawowej opieki zdrowotnej. Arter Hypertens. 2006; 10(5): 370-6.

8. Kozakiewicz K, Podolecka E, Syzdół M, et al. Relationship between education and cardiovascular risk score. Pol Arch Med Wewn. 2016; 126(5): 369-371, doi: 10.20452/pamw.3414, indexed in Pubmed: 27230774.

9. Klimek M, Knap J, Tulwin T, et al. Evaluation of the relationship between the incidence of diabetes and selected demographic factors. Clin Diabetol. 2018; 7(3): 145-150, doi: 10.5603/dk.2018.0010.

10. Dégano IR, Marrugat J, Grau M, et al. The association between education and cardiovascular disease incidence is mediated by hypertension, diabetes, and body mass index. Sci Rep. 2017; 7(1): 12370, doi: 10.1038/s41598-017-10775-3, indexed in Pubmed: 28959022.

11. Kershaw KN, Droomers M, Robinson WR, et al. Quantifying the contributions of behavioral and biological risk factors to socioeco- 
nomic disparities in coronary heart disease incidence: the MORGEN study. Eur J Epidemiol. 2013; 28(10): 807-814, doi: 10.1007/ s10654-013-9847-2, indexed in Pubmed: 24037117.

12. Chiara TDi, Scaglione A, Corrao S, et al. Education and hypertension: impact on global cardiovascular risk. Acta Cardiologica. 2017; 72(5): 507-513, doi: 10.1080/00015385.2017.1297626.

13. Wang J, Sun W, Wells GA, et al. Differences in prevalence of hypertension and associated risk factors in urban and rural residents of the northeastern region of the People's Republic of China. A crosssectional study. PLoS One. 2018; 13(4): e0195340, doi: 10.1371/ journal.pone.0195340, indexed in Pubmed: 29621328.

14. Molloy GJ, Stamatakis E, Randall G, et al. Marital status, gender and cardiovascular mortality: behavioural, psychological distress and metabolic explanations. Soc Sci Med. 2009; 69(2): 223-228, doi: 10.1016/j.socscimed.2009.05.010, indexed in Pubmed: 19501442 . 